Institute of $\mathbf{F}_{\text {ood and }} \mathbf{A}$ gricultural $\mathbf{S}_{\text {ciences }}$

\title{
Florida Solid and Hazardous Waste Regulation Handbook: State Agency Structuring ${ }^{1}$
}

Michael T. Olexa, Aaron Leviten, and Kelly Samek ${ }^{2}$

The majority of Floridas state agencies have similar structures. Most agencies maintain their headquarters in Tallahassee and have regional offices throughout the state. Within each agency, there are various divisions, each with its own set of duties. Examples of such divisions include administration, permitting, enforcement, and public information. Within each division is a structure of even greater specificity-the bureau. These handle many of the divisional duties at a more local level.

\section{How Is the Leader of an Agency Selected?}

Agency heads are either elected or appointed. They keep in close touch with the Governor and most participate in state government as part of the state Cabinet. Agency heads also stay in close contact with the state Legislature to keep up with policy changes and to maintain accurate, up-to-date rules. Agency decisions are all made at the will of the legislature to some extent since it controls the annual budgets for

the agencies. The legislature in its oversight capacity may also request information from the agencies and can create and destroy agencies, as long as they are not constitutionally-created agencies such as the Florida Fish and Wildlife Conservation Commission.

\section{Acknowledgments}

The authors are indebted to the personnel of both state and federal agencies who gave their time and advice in the preparation of this handbook. The authors are also indebted to the following University of Florida personnel for a review and critique of the first draft of this publication: Dr. Thomas Dean, Pesticide Education Specialist, and Dr. Norman Nesheim, Pesticide Information Coordinator. Special recognition is also due to Mr. Richard Budell of the Office of Agricultural Water Policy of the Florida Department of Agriculture and Consumer Services for providing funds for the development of this handbook.

This handbook is designed to provide an accurate, current, and authoritative summary of the principal Florida laws that directly or indirectly relate

1. This is EDIS document FE455, a publication of the Department of Food and Resource Economics, Florida Cooperative Extension Service, UF/IFAS, University of Florida, Gainesville, FL. Published December 2003. Please visit the EDIS website at http://edis.ifas.ufl.edu.

2. Michael T. Olexa, Professor in the Department of Food and Resource Economics and Director of the Agricultural Law Center, Florida Cooperative Extension Service, UF/IFAS, University of Florida, Gainesville, FL, and Member of the Florida Bar and Chair of the Agricultural Law Committee of the Florida Bar; Aaron Leviten, Attorney in Orlando and guest lecturer on pesticide litigation at the University of Florida; and Kelly Samek, 2003 graduate of the Levin College of Law at the University of Florida.

The Institute of Food and Agricultural Sciences is an equal opportunity/affirmative action employer authorized to provide research, educational information and other services only to individuals and institutions that function without regard to race, color, sex, age, handicap, or national origin. For information on obtaining other extension publications, contact your county Cooperative Extension Service office. Florida Cooperative Extension Service/Institute of Food and Agricultural Sciences/University of Florida/Christine Taylor Waddill, Dean. 
to agriculture. It should provide a basic overview of the many rights and responsibilities farmers and farmland owners have under Florida laws. The reader is provided information about these rights and responsibilities and the appropriate contacts for more detailed information. However, the reader should be aware that because the laws, administrative rulings, and court decisions on which this publication is based are subject to constant revision, portions of this publication could become outdated at any time. Many details of cited laws are also left out due to space limitations.

This handbook is distributed with the understanding that the authors are not engaged in rendering legal or other professional advice and the information contained herein should not be regarded or relied upon as a substitute for professional advice. It is not all-inclusive in providing information to achieve compliance with laws and regulations governing the practice of agriculture. For these reasons, the use of these materials by any person constitutes an agreement to hold harmless the authors, UF/IFAS, the Agricultural Law Center, and the University of Florida for any liability claims, damages, or expenses that may be incurred by any person as a result of reference to or reliance upon the information contained in this publication. 